\title{
Erratum to: "Interaction of Electromagnetic Radiation with a Thin Metal Wire in the Case of a Glancing Incident Wave" [Journal of Communications Technology and Electronics 62, 205 (2017)]
}

\author{
N. G. Kokodii ${ }^{a, b}$, *, M. V. Kaydash ${ }^{b}$, V. A. Timaniuk ${ }^{b}$, and I. A. Priz ${ }^{a}$ \\ ${ }^{a}$ Vasyl Karazin Kharkiv National University, Kharkiv, 61022 Ukraine \\ ${ }^{b}$ Kharkiv National University of Pharmacy, Kharkiv, 61002 Ukraine \\ *e-mail: Kokodiy.N.G@gmail.com \\ Submitted July 7, 2017; accepted for publication July 8, 2017
}

DOI: $10.1134 / \mathrm{S} 1064226917130010$

The name of the second author should read M. V. Kaydash.

The affiliation under the symbol " $a$ " should read:

Vasyl Karazin Kharkiv National University, Kharkiv, 61022 Ukraine 